\title{
(2) OPEN ACCESS \\ Cytology in the time of coronavirus disease (COVID-19): an Italian perspective
}

\author{
Elena Vigliar, Antonino laccarino, Dario Bruzzese, Umberto Malapelle (ㄷ) , \\ Claudio Bellevicine, Giancarlo Troncone
}

Department of Public Health, University of Naples Federico II, Naples, Italy

\section{Correspondence to}

Professor Giancarlo Troncone, Department of Public Health, University of Naples Federico II, Naples 5 I-80131, Italy; giancarlo.troncone@unina.it

Received 1 April 2020 Accepted 8 April 2020 Published Online First 20 April 2020
Check for updates

(C) Author(s) (or their employer(s)) 2021. Re-use permitted under CC BY-NC. No commercial re-use. See rights and permissions. Published by BMJ.

To cite: Vigliar $\mathrm{E}$, laccarino $\mathrm{A}$ Bruzzese D, et al. J Clin Pathol 2021:74:261-263.

\begin{abstract}
Introduction The coronavirus disease 2019

(COVID-19) is changing the way we practice pathology, including fine needle aspiration (FNA) diagnostics.

Although recommendations have been issued to prioritise patients at high oncological risk, postponing those with unsuspicious presentations, real world data have not been reported yet.

Methods The percentages of the cytological sample types processed at the University of Naples Federico II, during the first 3 weeks of Italian national lockdown were compared with those of the same period in 2019.

Results During the emergency, the percentage of cytology samples reported as malignant increased $(p<0.001)$, reflecting higher percentages of breast $(p=0.002)$ and lymph nodes FNAs $(p=0.008)$, effusions $(p<0.001)$ and urine $(p=0.005)$. Conversely, thyroid FNAs $(p<0.001)$ and Pap smears $(p=0.003)$ were reduced.

Conclusions Even in times of COVID-19 outbreak, cytological examination may be safely carried out in patients at high oncological risk, without the need to be postponed.
\end{abstract}

\section{INTRODUCTION}

At the University of Naples 'Federico II', cytopathology has been practised for many years. Earlier activity was related to exfoliative cytopathology. Then, following the example of the Karolinska Institute in Sweden, a cytopathologist-run fine needle aspiration (FNA) biopsy clinic was established. Thus, since 1976, cytopathologists have been performing FNAs by themselves, ensuring correct sample management, rapid on-site evaluation (ROSE) and, more recently, ultrasound guidance. This activity, carried out for more than four decades, is now being challenged by the extraordinary outbreak of the coronavirus disease 2019 (COVID-19) in Italy. ${ }^{1}$ Our country has overtaken China as the nation with the most coronavirusrelated deaths. From the epicentre, located in the north of the country, the disease is spreading more towards south, also involving the crowded Naples, the third-largest city of Italy after Rome and Milan.

In a very dramatic speech delivered to the nation on 9 March 2020, the Italian prime minister described the outbreak as the most difficult domestic crisis of the postwar period, deeming aggressive containment measures necessary, even if limiting freedom, privacy and individual rights. ${ }^{2}$ The national lockdown was imposed, and people were required to remain in their home. Italians transformed their lives. Accordingly, also our practice of cytopathology changed. Due to the potential presence of the virus in cytology specimens, we adopted more stringent safety procedures, according to recent recommendations. ${ }^{3-7}$ A policy of sample prioritisation was also implemented. While cytological screening activities were reasonably postponed, our cytology laboratory continued to function providing the best possible service to (potential) oncological patients. As a result, rate of malignancy increased. How long this pandemic will last is uncertain. However, we argue that in all cases, featuring a not negligible risk of a malignant disease, the cytological examination may be safely carried out without the need to be postponed.

\section{METHODS}

This study reports on the activity of the cytopathology laboratory at the University of Naples 'Federico II', during the extraordinary COVID-19 outbreak in Italy. The first 3 weeks of Italian national lockdown were taken into consideration. To this end, all cytological reports issued from 9 March to 27 March 2020 were reviewed. To assess how this extraordinary time differed from a normal period, data were compared with those relative to 9 March-27 March in 2019.

In both groups, the total number of samples processed was recorded. The number of Pap smear, urine samples and effusions was detailed. The rate of thyroid, breast, lymph node, salivary gland and soft tissue ultrasound-guided FNAs performed at our clinic was obtained. The distribution of the diagnostic classes was evaluated, taking into consideration the rate of inadequate/insufficient for diagnosis, negative for malignancy, atypical, benign neoplasm, suspicious for malignancy and malignant samples.

Between-years variations in percentages of sample type, site and rate of malignancy were evaluated using the $\chi^{2}$ test or the Fisher's exact test, when appropriate. No adjustments were made for multiple comparisons. P values of less than 0.05 were deemed as statistically significant.

\section{RESULTS}

Data relative to the period from the 9 March-27 March of 2019 were compared with those of the same days of 2020 when the COVID-19 outbreak took place. During the healthy emergency, less samples $(n=94)$ were processed compared with 2019 $(n=615)$. Exfoliative cytological samples dropped from $n=324$ to $n=56$, while ultrasound-guided 


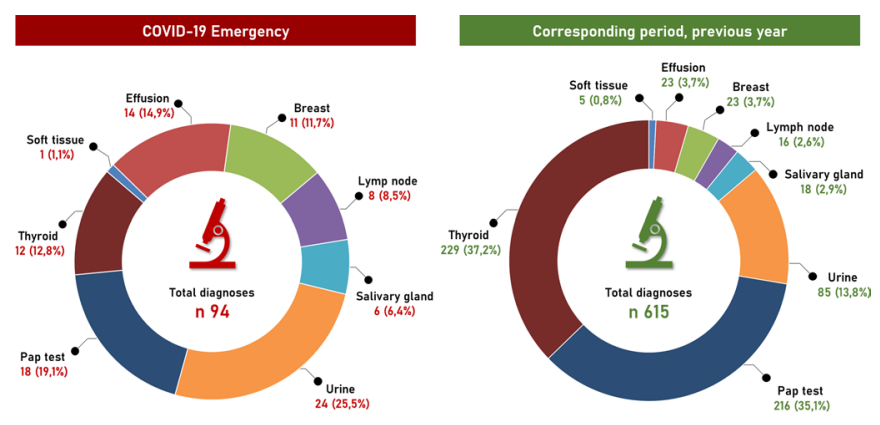

Figure 1 Distribution of cytological sample types during the first 3 weeks of Italian national lockdown amid COVID-19 outbreak compared with data relative to the activity from the same period in 2019.

FNAs were reduced from $n=291$ to $n=38$. In particular, differences were very evident when considering Pap smears $(n=216$, $35.1 \%$ vs $\mathrm{n}=18,19.1 \% ; \mathrm{p}=0.003)$. Urine $(\mathrm{n}=85,13.8 \%$ vs $\mathrm{n}=24,25.5 \% ; \mathrm{p}=0.005)$ and effusion $(\mathrm{n}=23,3.7 \%$ vs $\mathrm{n}=14$, $14.9 \% ; \mathrm{p}<0.001)$ also differed among the two groups. The number of thyroid FNAs was greatly reduced $(\mathrm{p}<0.001)$ dropping from $n=229(37.2 \%)$ to $n=12(12.8 \%)$. A relative increase in breast $(n=23,3.7 \%$ to $n=11,11.7 \% ; p=0.002)$ and in lymph nodes FNAs ( $\mathrm{n}=16,2.6 \%$ to $=8,8.5 \%, \mathrm{p}=0.008)$ was also evident; less marked was the variation in salivary gland $(n=18$, $2.9 \%$ to $n=6,6.4 \% ; p=0.116)$ and soft tissue FNAs $(n=5,0.8 \%$ to $\mathrm{n}=1,1.1 \% ; \mathrm{p}=0.575$ ) (figure 1 ).

As far as the diagnostic category distribution is concerned, inadequate/insufficient for diagnosis samples were $\mathrm{n}=52$ (8 $\%)$ in 2019 and $n=10(11 \%)$ in $2020(\mathrm{p}=0.616)$. Negative for malignancy were $n=458(75 \%)$ in 2019 and $n=61(65 \%)$ in $2020(\mathrm{p}=0.067)$; atypical cases were $\mathrm{n}=52(8 \%)$ in 2019 and $\mathrm{n}=5(5 \%)$ in $2020(\mathrm{p}=0.402)$; neoplastic, benign neoplasms were $n=13(2 \%)$ in 2019 and $n=4(4 \%)$ in $2020(p=0.264)$. Suspicious for malignancy were $n=10(2 \%)$ in 2019 and none in $2020(\mathrm{p}=0.374)$; malignant cases were $\mathrm{n}=30(5 \%)$ in 2019 and $n=14(15 \%)$ in 2020 . This latter difference was statistically significant $(\mathrm{p}<0.001)$. Data are summarised in figure 2 .

\section{DISCUSSION}

The COVID-19 emergency forced in Italy the major healthcare institutions to revisit their organisation and practices. While research and laboratory activities were suspended and administrative staff were allowed to work from home, our hospital management recommended to limit, as much as possible, outpatient visit, rescheduling clinic appointments that were not urgent (figure 3). Thus, the priority of periodic cervical cancer screening
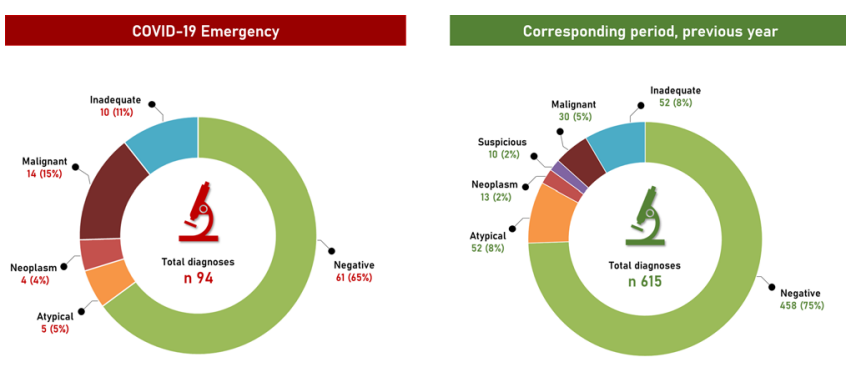

Figure 2 Distribution of the diagnostic classes relative to cytological samples processed during the first 3 weeks of Italian national lockdown amid COVID-19 outbreak compared with data relative to the activity from the same period in 2019.

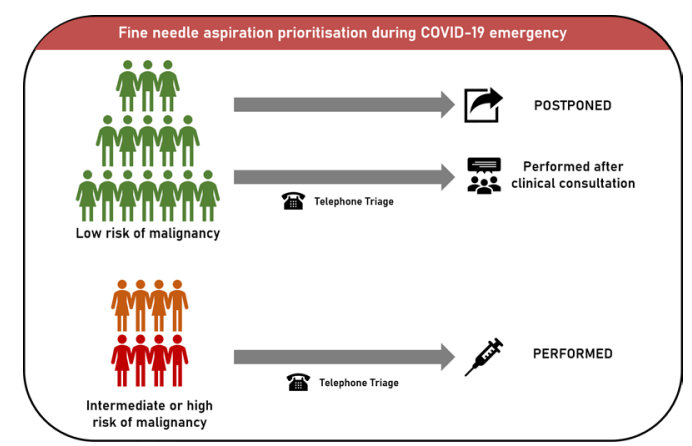

Figure 3 Patients prioritisation in cytopathologist-run FNA clinic. In patients at low oncological risk (ie, unsuspicious thyroid nodules), FNAs are postponed or performed only after the clinicians confirmed its opportunity. In patients at higher oncological risk (ie, breast lumps, lymph nodes enlargement), FNAs are performed as usual. To identify patients with COVID-19 symptoms, a telephone triage is performed. FNA, fine needle aspiration.

decreased and, compared with March 2019, the reduction of the Pap smears was marked $(\mathrm{p}=0.003)$.

Similarly, in patients at low oncological risk, such as those with unsuspicious thyroid nodules, FNA was postponed or performed only after the clinicians, including the general practitioners, confirmed its opportunity (figure 3). Relative increases were evident for enlarged lymph nodes $(p=0.008)$ and breast lumps $(\mathrm{p}=0.002)$. Considering the higher oncological risk, in these cases, FNAs were directly performed; patients were contacted by telephone the day before the FNA procedure to triage the presence of COVID-19 symptoms (figure 3). Salivary gland $(p=0.116)$ and soft tissue $(p=0.575)$ FNAs relatively increased only slightly. In contrast to Pap smears reduction, a relative increase was observed for both effusions $(p<0.001)$ and urine $(p=0.005)$, which is conceivable since these specimens are usually collected from symptomatic or oncological patients during follow-up.

The safety issues recently described by Pambuccian in a detailed review on the implication of the COVID-19 pandemic for cytopathology laboratories were carefully addressed. ${ }^{8}$ In many aspects our practice was revised to comply, as closely as possible, with the laboratory biosafety guidelines. ${ }^{3-79-11}$ Briefly, the FNA clinic used to be daily now runs on a weekly basis. This allows accurate disinfection and sterilisation and nurse rotation. Working in pairs, cytopathologists are faster, thus limiting the time spent in the clinic by each patient. Staff wear personal protective masks with a filter respirator and face shields to protect the eyes. As a general rule, smears are ethanol fixed to avoid that fluid and tissue materials obtained by FNA, expelled onto slides and allowed to dry, generated aerosols and droplets; these latter might contain viable and transmissible viruses. Lymph nodes smears are still air-dried as ROSE is needed to triage for flow cytometry or cell-block preparation. Safety procedures are also mandatory in laboratory when processing body fluids. These should be received, instead than fresh, ethanol fixed to ensure adequate virus inactivation. Finally, our informed consent form was changed to allow the possibility for the patient to receive the final diagnostic report by email.

In conclusion, here we report that, despite a drastic reduction in the number of the patient samples, sample prioritisation policy led our activity to yield a significant increase in the percentage of malignant cases diagnosed by cytological means $(\mathrm{p}<0.001)$. Despite the challenges of the COVID-19 extraordinary 
outbreak, cytological examination may be safely carried out making possible a relevant clinical service for high-risk oncological patients, thus continuing our four-decade practice.

\section{Handling editor Tahir S Pillay.}

Contributors EV, UM, CB and GT conceived the study and wrote the paper. Al collected the data. DB performed statistical analysis. All Authors approved the final version of the manuscript.

Funding The authors have not declared a specific grant for this research from any funding agency in the public, commercial or not-for-profit sectors.

Competing interests None declared.

Patient consent for publication Not required.

Provenance and peer review Not commissioned; internally peer reviewed.

Open access This is an open access article distributed in accordance with the Creative Commons Attribution Non Commercial (CC BY-NC 4.0) license, which permits others to distribute, remix, adapt, build upon this work non-commercially, and license their derivative works on different terms, provided the original work is properly cited, appropriate credit is given, any changes made indicated, and the use is non-commercial. See: http://creativecommons.org/licenses/by-nc/4.0/.

\section{ORCID iDs}

Umberto Malapelle http://orcid.org/0000-0003-3211-9957

Giancarlo Troncone http://orcid.org/0000-0003-1630-5805

\section{REFERENCES}

1 Livingston E, Bucher K. Coronavirus disease 2019 (COVID-19) in Italy. JAMA 2020;323:1335

2 Government of Italy. Decree of the President of the Council of ministers 9 March 2020, 2020. Available: https://www.gazzettaufficiale.it/eli/id/2020/03/09/20A01558/
3 Centers for Disease Control and Prevention (CDC). Interim laboratory biosafety guidelines for handling and processing specimens associated with coronavirus disease 2019 (COVID-19), 2020. Available: https://www.cdc.gov/coronavirus/2019-nCoV/lab/ lab-biosafety- guidelines.html

4 World Health Organization. Laboratory biosafety guidance related to the novel coronavirus (2019-nCov): interim quidance, 2020. Available: https://www.who.int/ docs/default-source/coronaviruse/ laboratory-biosafety-novel-coronavirus-version-1-1. pdf?sfvrsn=912a9847_2

5 SARS-CoV-2 (Severe acute respiratory syndrome-related coronavirus 2) - Canada. ca, 2020. Available: https://www.canada.ca/en/public-health/services/laboratorybiosafety-biosecurity/biosafety-directives-advisories-notifications/novel-coronavirusjanuary-27.html

6 COVID-19 - recommendations for laboratory work - Institute of Biomedical Science, 2020. Available: https://www.ibms.org/resources/news/covid-19-recommendationsfor-laboratory-work/

7 Iwen PC, Stiles KL, Pentella MA. Safety considerations in the laboratory testing of specimens suspected or known to contain the severe acute respiratory syndrome coronavirus 2 (SARS-CoV-2). Am I Clin Pathol.

8 Pambuccian SE. The COVID-19 pandemic: implications for the cytology laboratory. J Am Soc Cytopathol 2020. doi:10.1016/j.jasc.2020.03.001. [Epub ahead of print: 26 Mar 2020].

9 Raccomandazioni del comitato di citologia SIAPEC-IAP per la citologia dell'apparato respiratorio e del cavo orale in corso di emergenza da infezione COVID-19, 2020. Available: https://www.siapec.it/public/uploads/archiviodocumenti/COMUNICAZIONE COMITATO CITOLOGIA_COVID19.pdf

10 SIAPEC-IAP document: Gestione del rischio biologico correlato alla epidemia di COVID-19 nella manipolazione dei campioni tissutali E citologici, Con particolare riguardo Al campioni a fresco 0 non adeguatamente fissati, 2020. Available: https:// www.siapec.it/public/uploads/archiviodocumenti/Biosicurezza in anat pat 25 marzo 20 ver 3.pdf

11 RCPath advice on histopathology frozen sections and cytology fine needle aspiration during infectious disease outbreaks, 2020. Available: https://www.rcpath.org/ uploads/assets/034eb770-6b9e-4d2a-9b164fe7221bc289/b83ba8e9-f4fa-4f63844d9cade4f179f3/RCPath-advice-on-histopathology-frozen-sections-and-cytologyfine-needle-aspiration-during-infectious-disease-outbreaks.pdf 